\title{
ENDANGERED MEDIA BERBASIS MULTIMEDIA UNTUK PEMBERDAYAAN GURU-GURU SEKOLAH MINGGU (SUNDAY SCHOOL)
}

\author{
Titi Nur Vidyarini ${ }^{1 *}$ dan Gatut Priyowidodo ${ }^{1}$ \\ ${ }^{1}$ Program Studi Ilmu Komunikasi, Fakultas Ilmu Komunikasi, Universitas Kristen Petra \\ Jl. Siwalankerto 121-131, Surabaya, 60236 \\ *Korespondensi penulis, email: vidya@petra.ac.id, gatpri@petra.ac.id
}

\begin{abstract}
Abstrak: Kegiatan pengabdian masyarakat ini dilakukan untuk memperkenalkan metode mengajar atau komunikasi dalam kelas yang melibatkan multimedia. Sasaran dari kegiatan ini adalah guru-guru sekolah minggu atau disebut juga Pamong Kebaktian Anak di Gereja GKJW Madiun dan GKJW Rungkut. Selama ini proses pengajaran sekolah minggu dilakukan dengan menggunakan sarana bahasa verbal dan nonverbal dari pamong KA, yang bisa disebut sebagai media tradisional atau endangered media. Perkembangan multimedia di era saat ini telah menyentuh anak-anak dan remaja yang mengikuti pendidikan agama secara informal di Sekolah Minggu. Melalui kegiatan ini, para pengabdi masyarakat mencoba memperkenalkan penggunaan multimedia, seperti laptop, tablet dan aplikasi video klip dalam proses pembelajaran di Sekolah Minggu. Tahap pertama adalah melalui pengenalan karakteristik anak dan media yang dapat digunakan. Tahap selanjutnya adalah pengenalan multimedia.
\end{abstract}

Kata kunci: Endangered media, verbal dan nonverbal, Sekolah minggu, multimedia, karakteristik anak.

\begin{abstract}
The community service was conducted to introduce multimedia-based teaching or in class communication method. The program is targeting Sunday school teachers or known as Pamong Kebaktian Anak (Kid's church) at GKJW Madiun Lor in Madiun and GKJW Rungkut in Surabaya. The class emphasised on the use of verbal and nonverbal communication method, or traditional media. Nowadays the development of multimedia has touched the children and teenagers who learn informal religion education of Sunday School. Through this activity, we tried to introduce the use of multimedia, such as laptop, tablet and video clip application in the teaching process. The first stage is to know the characteristic of the children or target audience. The next stage is to introduce the multimedia application.
\end{abstract}

Keywords: Endangered media, verbal and nonverbal, Sunday School, multimedia, children characteristic.

\section{PENDAHULUAN}

Komunikasi publik terjadi dalam berbagai konteks, salah satunya adalah komunikasi dalam ruang kelas. Pendidikan formal di Indonesia berangkat dari komunikasi satu arah dimana dasar pendidikan adalah teacher-centered. Namun dengan perkembangan masyarakat saat ini dan munculnya sistim pendidikan KBK (Kurikulum Berbasis Kompetensi), proses belajar mengajar diarahkan menjadi student-centered learning. Sistem pembelajaran yang terakhir menekankan adanya interaktivitas antara guru dan murid, dengan mengutamakan keaktifan murid. Johnson (1999) mengungkapkan bahwa pengajar atau guru akan menyadari bahwa berkomunikasi dimulai dari lingkungan, guru yang baik tidak hanya berbicara namun juga menjadi pendengar yang baik. Komunikasi dalam ruang kelas yang kondusif adalah ketika murid memahami materi dari guru dan dapat memberikan umpan balik, dalam bentuk pertanyaan atau sanggahan, yang dapat memulai diskusi dan interaktivitas dalam kelas. Pendidikan formal di sekolah dasar hingga sekolah menengah atas memiliki kurikulum dan metode pengajaran yang disarankan. Hendriyani, Armando dan Atmonobudi (2009) menemukan dalam penelitian mereka terkait YPMA, bahwa media dapat mempengaruhi anakanak, sehingga pengajar pun harus menemukan cara yang kreatif untuk memanfaatkan media yang ada dalam proses belajar mengajar. Selain itu, Hendriyani, Armando dan Atmonobudi juga 
menemukan hambatan yang dihadapi pengajar media di Indonesia, salah satunya adalah kemampuan guru dalam metode pengajaran, dimana guru harus memiliki pengetahuan tentang media, dilengkapi ketrampilan untuk membuat kelas menjadi kreatif dan menyenangkan (2006, pp. 11-12)

Hal yang berbeda dapat terjadi untuk kelas atau proses pendidikan informal. Sebagai contohnya adalah pendidikan yang terjadi dalam konteks homeschooling, pendidikan dalam bentuk pendampingan kepada anak-anak jalanan dalam kelas-kelas yang lebih kecil, dan sebagainya. Sekolah Minggu merupakan bentuk pengajaran informal bagi anakanak jemaat, dilakukan bersamaan dengan kegiatan ibadah Gereja. Materi yang disampaikan adalah seputar isi Alkitab, saran kehidupan sehari-hari dan aktivitas yang mendukung materi utama. GKJW Jemaat Madiun Lor dan GKJW Rungkut merupakan dua gereja yang berada di bawah Majelis Agung GKJW. Proses pendidikan agama secara informal diselenggarakan dengan nama Kebaktian Anak atau terkadang disebut sebagai Sekolah Minggu. Baik di GKJW Surabaya Rungkut atau GKJW Madiun Lor, Sistim Sekolah Minggu mulai bergeser model penamaannya menjadi sistim BKA dan kemudian KA (Kebaktian Anak) tetapi istilah umumnya tetap sama yakni kegiatan pengajaran di Sekolah Minggu. Sekolah Minggu berada di bawah koordinasi Komisi Pembinaan Anak dan Remaja (KPAR) setiap gereja. Sekolah Minggu atau Kebaktian Anak (KA) terbagi atas empat jenjang yakni kelas Balita, kelas Pratama (SD Kelas 1-3), kelas Madya (SD kelas 4-6) dan kelas Remaja (SMP hingga usia 16 Tahun).

Pengajar Sekolah Minggu tidak memiliki kurikulum tetap, selain buku panduan yang diterbitkan oleh Gereja. Materi diambilkan dari buku tersebut dan diajarkan dengan berbagai metode pada kepada anak-anak jemaat dengan usia bervariasi dari balita hingga remaja usia 16 tahun. Penyampaian materi yang berdasar dari Alkitab dan contoh-contoh kehidupan keseharian bukanlah hal yang mudah. Komunikasi secara verbal dilakukan dengan berbagai modifikasi, disesuaikan dengan usia anakanak. Meski demikian kebutuhan terhadap multimedia nampak dari penggunaan smartphone dan berbagai multimedia saat anak-anak dan remaja mengikuti KA.

\section{METODOLOGI}

Kegiatan pengabdian masyarakat ini dimulai dengan observasi dan wawancara dengan pihak Sekolah Minggu. Pengabdi masyarakat menemui KPAR (Komisi Pembinaan Anak dan Remaja) di kedua gereja.

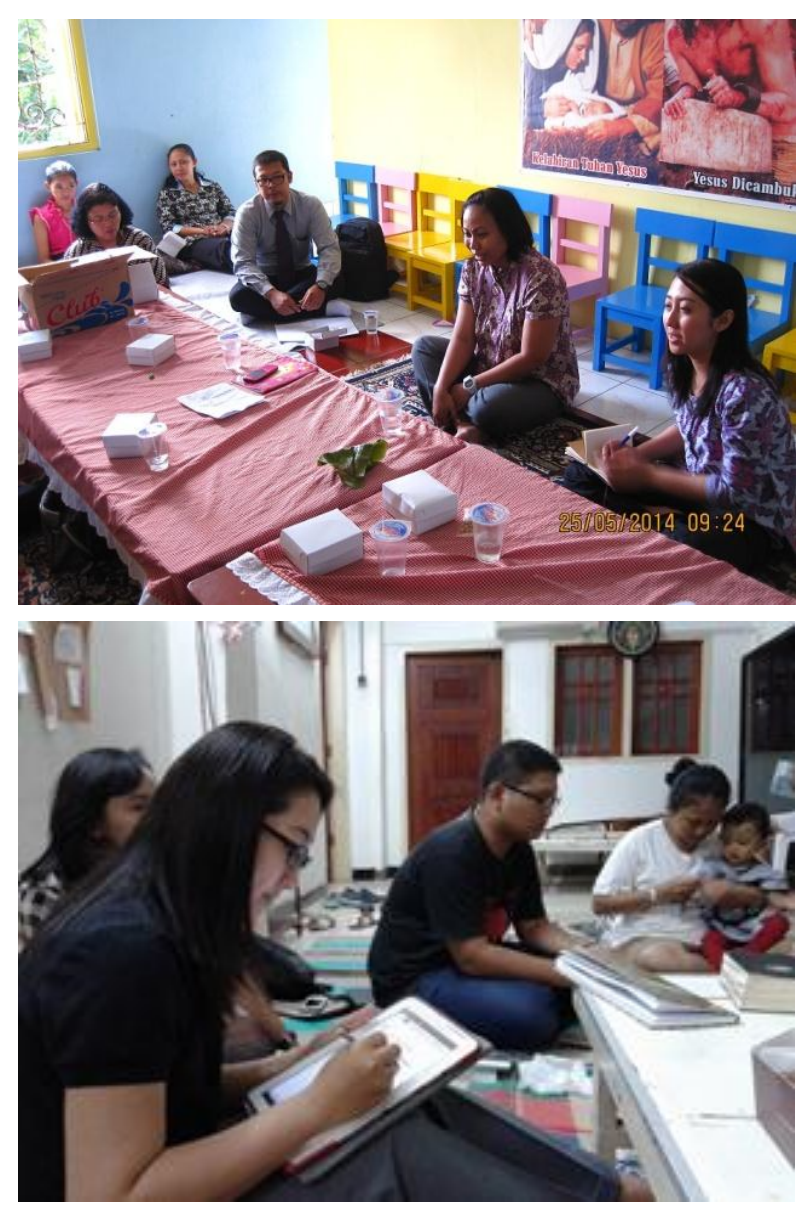

Pertemuan dengan KPAR diisi dengan membahas beberapa hal, yakni:

1. Kondisi Kebaktian Anak di kedua gereja.

2. Kondisi dan latar belakang pamong pengajar $\mathrm{KA}$.

3. Keberadaan dan penggunaan multimedia saat Sekolah Minggu.

4. Kondisi kelas Sekolah Minggu

Selama proses pertemuan, para pamong mengungkapkan kebutuhan mereka terkait alat peraga dan multimedia. Dari kedua gereja tersebut, GKJW Madiun Lor mengungkapkan minimnya alat peraga dan multimedia saat Sekolah Minggu. Hal ini didukung pula dengan minimnya multimedia yang dimiliki oleh Gereja.

GKJW Rungkut telah mengenal multimedia, mayoritas pamong menggunakan smartphone dan terkadang menggunakan laptop untuk menampilkan video kepada anak-anak. Meskipun demikian perlengkapan tersebut adalah milik pribadi dan bukan gereja.

\section{Sasaran Kegiatan}

Sasaran kegiatan ini adalah para pamong kedua gereja. Pamong kedua gereja tersebut terdiri dari laki-laki dan perempuan yang berlatarbelakang 
pendidikan dan usia yang bervariasi. Pamong GKJW Madiun Lor berjumlah 16-17 orang, mayoritas dari mereka berusia sekitar 30-40 tahun, minoritasnya berusia 20-25 tahun. Latarbelakang mereka mayoritas adalah pekerja dan ibu rumah tangga. Sementara itu, pamong GKJW Rungkut berjumlah sekitar 45-50 orang, yang mayoritas adalah mahasiswa dan orang yang baru bekerja, atau sekitar usia 20-40 tahun.

\section{PEMBAHASAN}

\section{Pengenalan Karakteristik Anak dan Pesan yang Sesuai}

Pada tahap ini, materi di GKJW Rungkut dan GKJW Madiun Lor disampaikan oleh ibu Titi Nur Vidyarini, S.Sos., M.Comms. dan Bapak Gatut Priyowidodo, Ph.D. Pengenalan terhadap karakter dan gaya belajar anak sangat penting untuk membuat materi dan metode belajar. Secara khusus hal ini bermanfaat untuk para pamong dalam menyampaikan materi mengenai firman Tuhan. Hal ini sesuai yang disampaikan oleh Setiawani (2000, p. 177) "nilai pendidikan agama ditunjukkan melalui bimbingan terhadap anak dengan memasukkan pelajaran agama ke dalam perilaku dan pengalaman anak-anak". Dia menambahkan bahwa, "para pakar ilmu jiwa mengakui keteladanan hidup beragama dalam keluarga sangat bernilai, misalnya sewaktu makan berdoa atau pergi ke gereja bersama".

Materi pertama adalah mengenai gaya belajar dan kecerdasan anak:

a. Multiple Intelligence (Armstrong, 2003),

1. Delapan jenis kecerdasan ditemukan oleh Dr. Howard Gardner. Alternatif dari tes IQ standar.

2. Kecerdasan adalah kemampuan untuk memecahkan masalah dan menciptakan produk yang mempunyai nilai budaya.

3. Membantu pamong untuk mengenali kecenderungan anak dalam menangkap firman Tuhan.

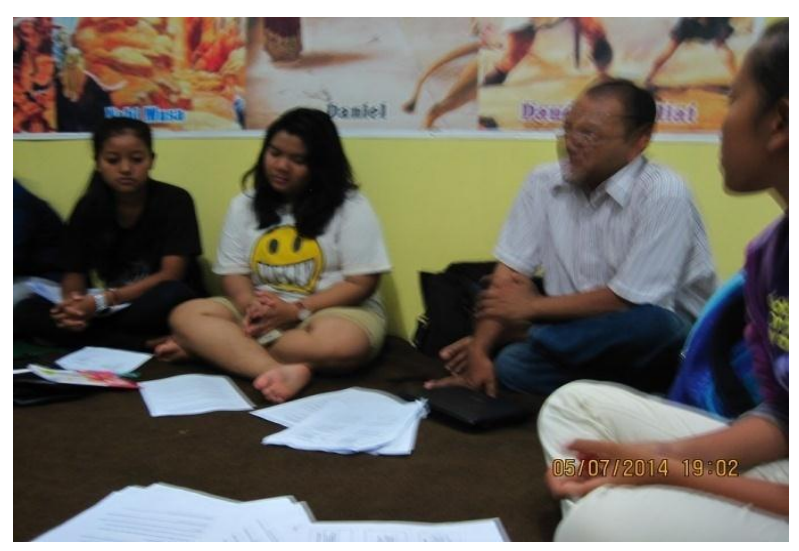

b. Bentuk Kecerdasan Anak

Menurut Armstrong (2003), setiap anak dilengkapi dengan 8 jenis kecerdasan. Menonjol atau tidaknya kecerdasan tersebut tergantung pada situasi dan kondisi belajar yang dihadapi anak. Delapan kecerdasan tersebut adalah:

1. Kecerdasan Linguistik: Kemampuan menggunakan kata-kata secara efektif. Berkaitan dengan kemampuan berbicara.

2. Kecerdasan Logis-Matematis: Ketrampilan mengolah angka dan/atau kemahiran menggunakan logika/akal sehat.

3. Kecerdasan Spasial: Kecerdasan gambar dan visualisasi. Kemampuan menciptakan gambar dua-tiga dimensi dalam benak seseorang.

4. Kecerdasan Jasmani: Kecerdasan seluruh tubuh dan tangan. Individu yang memiliki koordinasi motorik baik.

5. Kecerdasan Musikal: Kemampuan menyanyikan lagu, mengingat melodi musik, punya kepekaan irama atau menikmati musik.

6. Kecerdasan Antar Pribadi: Kemampuan memahami dan bekerja dengan orang lain. Kemampuan berempati, berteman, dan ketrampilan menjalin kontak atau relasi.

7. Kecerdasan Intrapribadi: Kecerdasan memahami diri sendiri. Kecerdasan mengetahui kelebihan dan kelemahan diri.

8. Kecerdasan Naturalis: Kemampuan mengenali bentuk-bentuk alam di sekitarnya.

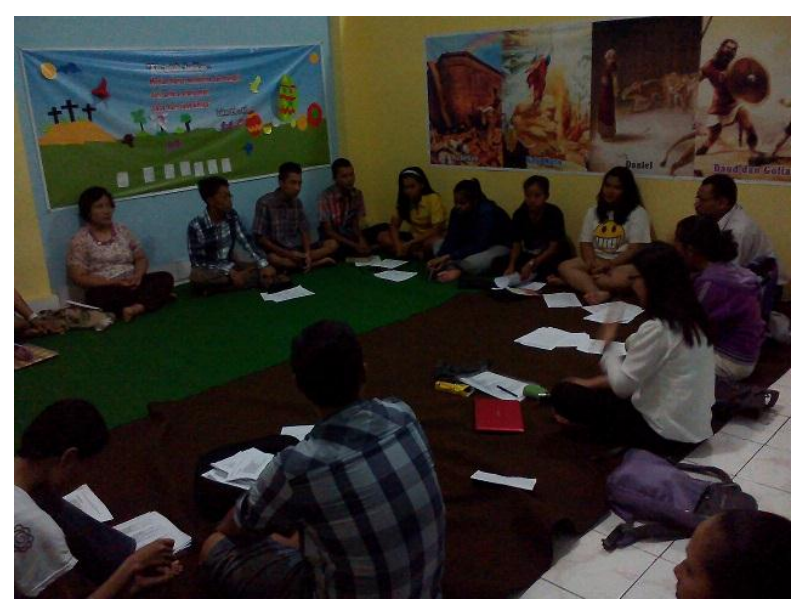

Komunikasi dan Multimedia dalam Pembelajaran

Johnson (1999, p. 7) dalam penelitiannya menekankan peran dari komunikasi verbal dan nonverbal dalam mendukung efektivitas komunikasi dalam kelas, "Effective communication in the classroom requires the teacher and students to be able to send and receive messages accurately. Nonverbal communication is by no means the most effective way to achieve this goal, however it is one of the many ways that is acceptable in the classroom." (komunikasi 
yang efektif dalam kelas membutuhkan guru dan murid dapat mengirim dan menerima pesan yang akurat, komunikasi nonverbal memang bukan cara yang paling efektif untuk mencapai sasaran ini, tapi ini adalah salah satu metode yang bisa diterima dalam kelas.)
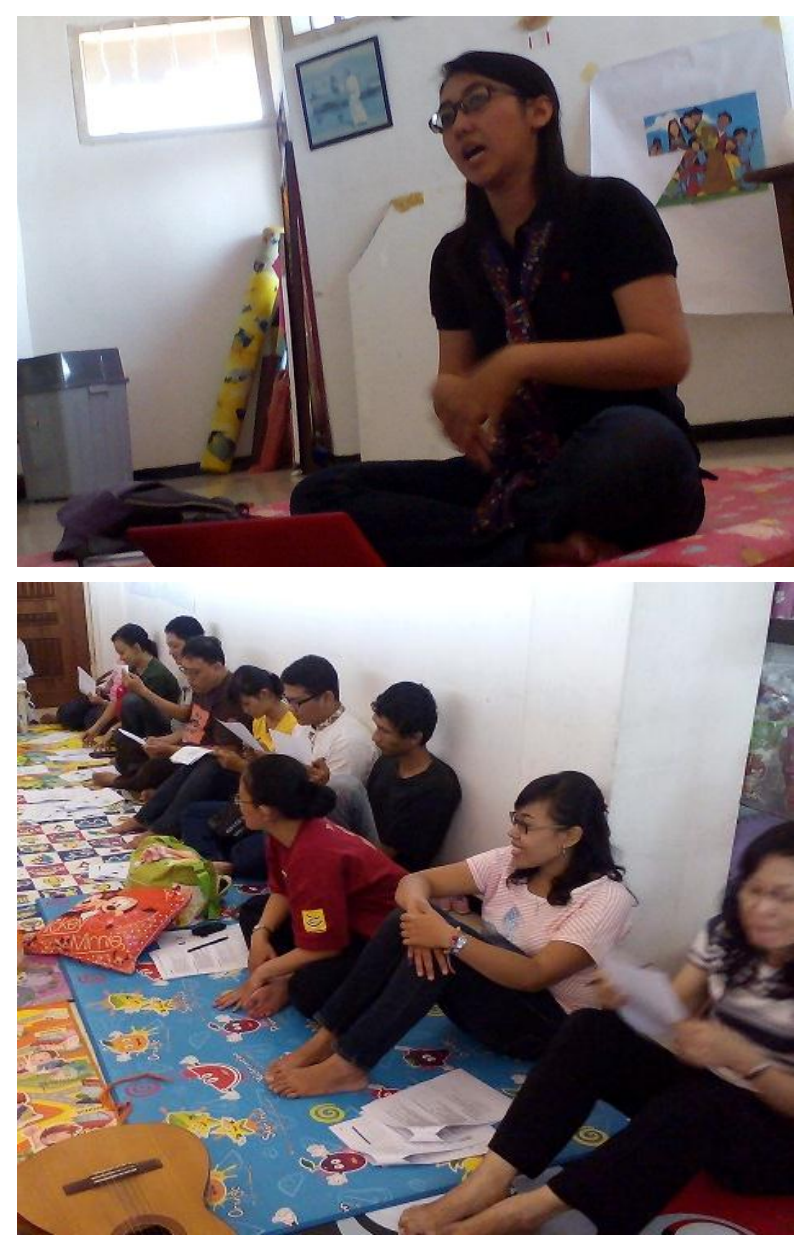

Pada tahap ini ibu Titi Nur Vidyarini memberikan materi mengenai strategi komunikasi dalam kelas yang diadaptasi dari model pembelajaran ASSURE. Model strategi kelas ini diadaptasi dalam bentuk pengelolaan komunikasi kelas, diantaranya adalah (Smaldino, Lowther, dan Russel, 2012, p. 39):

1. Mengenali anak-anak yang diajar

2. Membuat sasaran/objektif pembelajaran

3. Pilih strategi/metode pembelajaran

Pada tahap ini pengajar menyesuaikan media yang tepat dengan usia dan tingkat belajar anak, serta hasil akhir pembelajaran yang diharapkan. Saat mengaplikasikan strategi tersebut, pada tahap ini dapat mengadaptasi komunikasi nonverbal dari DeVito. DeVito (2006) menjelaskan saluran pesan nonverbal diantaranya, body, gerak dan penampilan tubuh seseorang; facial communication, elemen dari wajah seperti mata yang pergerakannya dapat memberikan makna tertentu; space communication, jarak antar pribadi yang dimiliki seseorang ketika berhadap- an dengan orang lain; touch communication, sentuhan tangan seseorang pada orang lain yang merupakan bentuk paling primitif dalam komunikasi; dan paralanguage, dimensi nonverbal dari bahasa tutur, seperti penekanan yang diucapkan pada kata tertentu (pp. 136-152).

4. Utilisasi teknologi, media dan materi

Tahap ini memerlukan pengajar untuk dapat meninjau materi dan media, mengaplikasikan media, menyiapkan lingkungan yang sesuai, menyiapkan si anak, dan menyediakan pengalaman belajar.

5. Peran serta anak

Agar komunikasi dalam pengajaran berjalan efektif maka diperlukan keterlibatan mental si anak. Pengajar harus menyediakan aktivitas yang melatih anak untuk mempraktikkan pengetahuan dan ketrampilan baru dan menerima umpan balik sebagai penilaian mereka (Smaldino, Lowther, dan Russell, 2012, p. 39).

6. Evaluasi pembelajaran

Evaluasi pembelajaran dapat meliputi tercapainya sasaran awal pembelajaran, proses instruksional (dan komunikasi) dan dampak teknologi atau media yang digunakan.

Selain itu para pengabdi juga memberikan materi dalam hal penyesuaian multimedia dengan usia anak yang diajar. Beberapa bentuk media yang disarankan adalah:
a. Gambar
b. Peraga 4 dimensi
c. Video
d. Audio/podcast
e. komputer atau laptop
f. papan permainan
g. role play

Pada tahap ini pula, para pengabdi dibantu oleh Ibu Esti Kurnianingsih, S.Psi. yang memberikan materi terkait Psikologi anak dan media pembelajaran yang tepat,

1. Balita

a. Mengajarkan Alkitab dalam konteks aktivitas dan pengalaman.

b. Informasi alkitabiah disampaikan sesuai dengan level pemahaman mereka, misal "Tuhan itu maha hadir" diganti dengan kalimat "Tuhan selalu melihat kita"

c. Guru harus memperlengkapi diri dengan berbagai metode yang menarik dan menyenangkan anak dalam setiap pertemuan.

d. Aktivitas harus dirangkai menjadi suatu kesatuan utuh untuk menyampaikan pesan yang sama, mulai dari pujian, permainan, alat peraga, aktivitas, dsb

e. Usia 4-5 tahun, anak-anak mengembangkan konsep tentang dunia ini, karena itu kita 
harus mengisinya dengan dasar-dasar kebenaran agar mereka mendapat pengertian yang alkitabiah.

f. Materi pengajaran berpusat pada pengalaman, seperti kehidupan dalam keluarga, penciptaan dan pemeliharaan Allah, dst
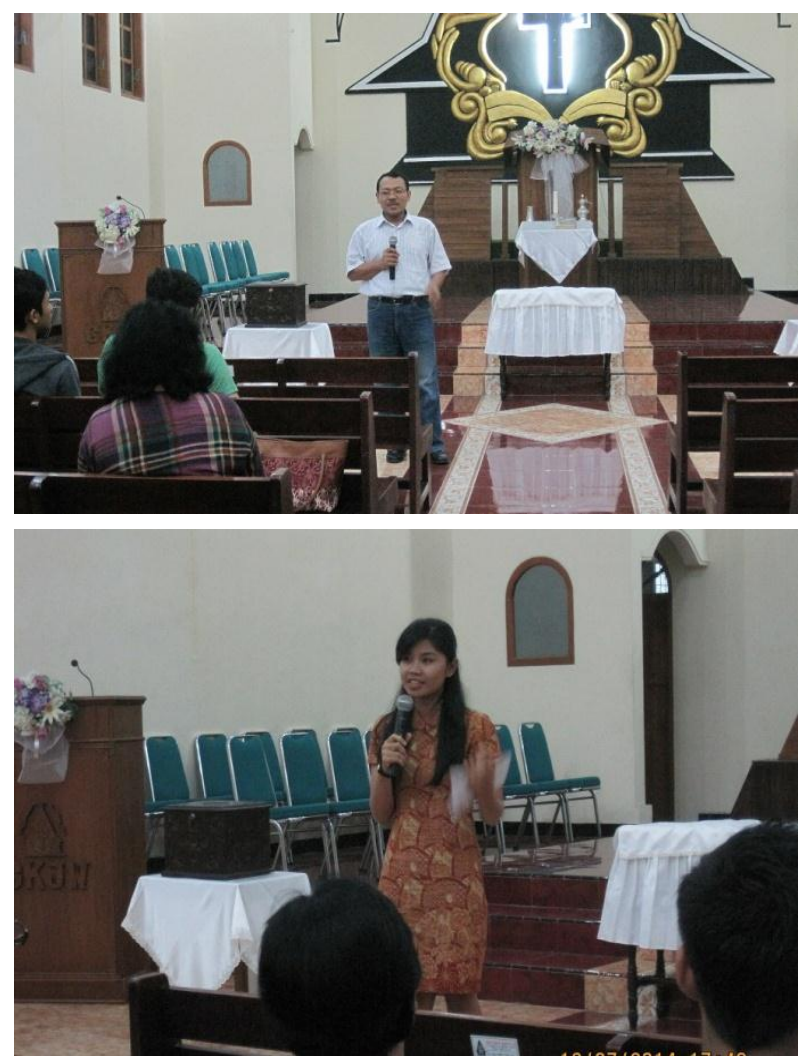

g. Usia 6 tahun, dapat disampaikan kisah-kisah alkitab, perikop yang disampaikan dapat lebih panjang dan lengkap, misal tema "setia pada Tuhan" dapat menggunakan kisah Daniel, dan kisah Yusuf, pada usia ini anak dapat mengerti hubungan satu peristiwa ke peristiwa lainnya.

h. Metode drama, boneka tangan, boneka kertas, role play dapat membuat penyampaian materi jadi lebih menarik.

i. Menirukan gerakan tertentu, atau memasukkan materi dalam permainan juga membuat anak tidak mudah bosan.

j. Metode dongeng tidak boleh dengan nada suara monoton, perhatikan intonasi, jika perlu berbagai tipe suara untuk menggambarkan masing-masing tokoh, perhatikan ekspresi. Jangan terlalu panjang, berikan penekanan pada point yang akan ditanamkan, jika perlu diulang.

k. Aktivitas sederhana seperti gunting-lipattempel yang sederhana dan mewarnai

\section{Pratama}

a. Dasar pertimbangannya adalah bahwa alkitab dilihat secara keseluruhan dari segi sejarah, diperkenalkan mulai PL hinga PB. b. Perkenalkan tokoh-tokoh Alkitab yang menjadi teladan, karena anak usia ini mulai punya idola.

c. Penyampaian materi juga harus kreatif, karena anak masih mudah bosan sekalipun mereka sudah dapat duduk tenang dalam waktu yang lebih lama

d. Memberi tayangan video/film

e. Mengajak anak-anak field trip, ibadah padang, dst

f. Membuat craft yang lebih rumit, yang membutuhkan kehati-hatian saat menggunting, kerapian, dan presisi saat menempel.

g. Sudah dapat memahami alur cerita, memvisualisasikan dalam imajinasinya keadaan kota, jalan, cuaca, dst. Dapat memahami silsilah, budaya, setting cerita, dst.

h. Alat peraga harus yang dapat membuat kesan sehingga tidak mudah terlupakan

i. Gambar, lipat-gunting-tempel yang lebih rumit, puzzle

3. Madya

a. Metode cerita jangan melulu dongeng, mereka menyukai penyelidikan alkitab sendiri

b. Bisa dengan teka-teki, pertanyaan, yg melibatkan perkembangan kemampuan analisisnya.

c. Dapat dengan tanya jawab, diskusi, mencari fakta dalam alkitab, mencari sebab-alkitab, arti, perasaan, dst

d. Aplikasi dalam kehidupan sehari-hari, kebenaran yang mereka terima dikaitkan dengan bagaimana seharusnya mereka menyikapi permasalahan.

e. Alat peraga berupa foto Mesir, untuk memberi gambaran kebudayaan mereka, bagaimana perbudakan, dst, gambar sungai Yordan, Taman Getsemani, dst

f. Dapat juga dengan film.

4. Remaja

a. Metode diskusi, studi kasus, debat, problem solving, lebih menantang

b. Anggap mereka sebagai sahabat, bukan anak kecil yang harus diberi tahu ini-itu, tetapi ajak mereka berfikir

c. Jadilah sahabat bagi mereka, buat mereka nyaman untuk menceritakan masalah mereka

d. Untuk belajar alkitab, gunakan kamus alkitab, peta,buku sejarah, dst yang memberikan informasi yang lebih komprehensif

e. Topik aktual = pasangan hidup, sekolah, idola. Topik yang diangkat dalam materi sekolah minggu harus up-to-date

\section{KESIMPULAN}

Setelah pelaksanaan abdimas ini para pengabdi menemukan bahwa kedua Gereja tersebut memiliki 
kondisi pengajar, kondisi anak dan pengenalan multimedia yang berbeda. Materi yang diberikan kepada Sekolah Minggu GKJW Madiun Lor agak berbeda dengan materi untuk GKJW Rungkut. Hal ini dikarenakan, kebutuhan pengajar GKJW Madiun Lor berpusat pada keberadaan alat peraga dan mengenal karakteristik anak. Sementara itu kebutuhan GKJW Rungkut berpusat pada bagaimana berkomunikasi dengan anak dan penggunaan multimedia yang tepat. Secara keseluruhan dapat disimpulkan bahwa penggunaan multimedia untuk pengajaran sudah diperlukan, meskipun demikian media tersebut bukanlah media utama untuk proses Sekolah Minggu. Komunikasi dalam kelas masih mengutamakan tatap muka, verbal dan nonverbal dari pengajar yang disesuaikan dengan usia anak dan kelas mereka.

\section{UCAPAN TERIMA KASIH}

Para pengabdi masyarakat ingin mengucapkan terima kasih sebesar-besarnya kepada:

1. DIKTI (Dirjen Pendidikan Tinggi) yang memberikan hibah pengabdian masyarakat, sehingga kegiatan ini dapat terselenggara dengan baik.

2. LPPM (Lembaga Penelitian dan Pengabdian Masyarakat) UK Petra yang telah membantu memfasilitasi kegiatan ini.

3. Fakultas Ilmu Komunikasi UK Petra

4. Program Studi Ilmu Komunikasi UK Petra

5. Ibu Pdt. Retno Wahyuni dari GKJW Madiun Lor

6. Ibu Nova, KPAR GKJW Madiun Lor dan para Pamong

7. Bpk. Pdt. Wolter Kalangi, S.Th. dari GKJW Rungkut
8. Bpk. Petrus Julianto, KPAR GKJW Rungkut dan para Pamong

9. Ibu Esti Kurnianingsih, S.Psi. dan PKPP (Pusat Konseling dan Pengembangan Pribadi) UK Petra.

10. Ibu Myrna Basuki

\section{DAFTAR PUSTAKA}

Armstrong, T. (2003). Setiap anak cerdas: panduan membantu anak belajar dengan memanfaatkan multiple intelligencenya. Jakarta: PT Gramedia Pustaka Utama.

DeVito, J. A. (2006). Human communication: the basic course (10 ed.). Boston: Pearson Education.

Hendriyani, Armando, N. M., \& Atmonobudi, B. K. S. (2009). School based media education: sharing for experiences and lessons learned from Indonesia. retrived from http://www. unicef.org/indonesia/School_based_media_edu cation_in_Indonesia.pdf

Johnson, M. B. (1999). Communication in the classroom. ERIC, Georgia.

Setiawani, M. G. (2000). Menerobos dunia anak. Bandung: Yayasan Kalam Hidup.

Smaldino, S. E., Lowther, D. L., \& Russell, J. D. (2012). Instructional technology and media for learning (10 ed.). Boston: Pearson Education, Inc.

Laufer, Ruth \& Dyck, Anni, Pedoman pelayanan anak, diambil dari www.sabda.org

Richards, Lawrence O., Mengajar alkitab secara kreatif, diambil dari www.sabda.org 